EFFICINT

\title{
Analysis of Willingness to Pay Integrated Waste Management
}

\author{
Tionarta Bakara', Prasetyo Ari Bowo ${ }^{2}$ \\ Jurusan Ekonomi Pembangunan, Fakultas Ekonomi, Universitas Negeri Semarang \\ Permalink/DOI: https://doi.org/10.15294/efficient.v2i2.30805 \\ Received: December 2018 ; Accepted: March 2019; Published: Juny 2019
}

\begin{abstract}
Waste volume in Semarang City increases every year. Local Regulation Number 6 Year 2012 forces households to reduce waste through $3 R$. 83\% pre-survey citizens in West Semarang District have not done it yet. It needs an improvement on waste management. The purpose of this research is to know the citizen's willingness to pay rate of West Semarang District on waste management improvement and to analyze the factors affecting willingness to pay. The data used in this research is Primary Data. The population in this research is 100 households in West Semarang District. Data collection method is using interview. Data analysis method is using Contingent Valuation Method and multiple linear regression. The result shows that 68 respondents are willing to pay and 32 respondents are not. The amount of willingness to pay is Rp16.838. Influencing factors of willingness to pay are education level and staying duration. The recommendation of this research is the higher willingness to pay should be followed by better management service. Citizens can improve willingness to pay by having higher education level so that they realize the importance of maintaining environment. To increase willingness to pay, the higher family members the more they should have a good knowledge so that their perception about the payment based on head of the family will decrease.
\end{abstract}

Keywords: Management, waste, Willingness To Pay, Contingent Valuation Method

\begin{abstract}
Abstrak
Volume sampah di Kota Semarang meningkat setiap tahun. Peraturan Daerah Nomor 6 Tahun 2012 memaksa rumah tangga untuk mengurangi limbah melalui 3 R. 83\% warga pra-survei di Kabupaten Semarang Barat belum melakukannya. Perlu perbaikan dalam pengelolaan limbah. Tujuan dari penelitian ini adalah untuk mengetahui kesediaan warga untuk membayar tarif Kabupaten Semarang Barat pada peningkatan pengelolaan limbah dan untuk menganalisis faktor-faktor yang mempengaruhi kesediaan untuk membayar. Data yang digunakan dalam penelitian ini adalah Data Primer. Populasi dalam penelitian ini adalah 100 rumah tangga di Kabupaten Semarang Barat. Metode pengumpulan data menggunakan wawancara. Metode analisis data menggunakan Metode Contingent Valuation dan regresi linier berganda. Hasilnya menunjukkan bahwa 68 responden bersedia membayar dan 32 responden tidak. Jumlah kemauan untuk membayar adalah Rp16.838. Faktor-faktor yang mempengaruhi kemauan untuk membayar adalah tingkat pendidikan dan durasi tinggal. Rekomendasi dari penelitian ini adalah semakin tinggi kesediaan untuk membayar harus diikuti oleh layanan manajemen yang lebih baik. Warga dapat meningkatkan kemauan untuk membayar dengan memiliki tingkat pendidikan yang lebih tinggi sehingga mereka menyadari pentingnya menjaga lingkungan. Untuk meningkatkan kemauan membayar, semakin tinggi anggota keluarga semakin mereka harus memiliki pengetahuan yang baik sehingga persepsi mereka tentang pembayaran berdasarkan kepala keluarga akan berkurang.
\end{abstract}

Kata Kunci: Manajemen, limbah, Kesediaan Untuk Membayar, Metode Penilaian Kontinjensi

How to Cite: Bakara, T., \& Bowo, P. (2019). Analysis of Willingness to Pay Integrated Waste Management. EFFICIENT Indonesian Journal of Development Economics, 2(2), $461-468$. https://doi.org/10.15294/efficient.v2i2.30805

(c) 2019 Semarang State University. All rights reserved

\footnotetext{
Alamat Korespondensi :

Alamat: Gedung L2 Lantai 2 FE Unnes

Kampus Sekaran, Gunungpati, Semarang, 50229

E-mail : efficientjournal@gmail.com
}

ISSN 2655-6197 


\section{INTRODUCTION}

Living environment is an interrelation between human and other creatures (Reksohadiprodjo 2000). Environmental pollution is one of the negative effects and proof to natural resources damage currently faced by both developed and developing countries. Generally, environmental damage is caused by natural event, rapid population grow, exploitation and rubbish and waste. Rubbish as one of the main cause to environmental damage importantly becomes the environmental problems along with the rapid growing population and the increasing of development activities (Annisa 2015).

Indonesia is one of developed countries which experiences the increase of population every years. Based on CIA World Factbook in 2016, Indonesia ranked four by the most populated country with around 258 million people or $3.5 \%$ from the world's population. This fact makes Indonesia facing a serious problem into solid waste management issue produced by the household. Everyday, the waste production is highly happened in Java Island, for instance Jakarta, Surabaya and Semarang, whereas outside Java Island are in Medan, Denpasar and Makassar (Badan Pusat Statistik 2017).

Semarang is one of the big cities in Indonesia and is acting as the driving force of the economy has become a city with the highest waste production rate compared to any other major cities in Central Java, like Pekalongan, Magelang, Surakarta, Semarang and Tegal. The picture below explains about the waste amount produced by major cities in Central Java in 2016.

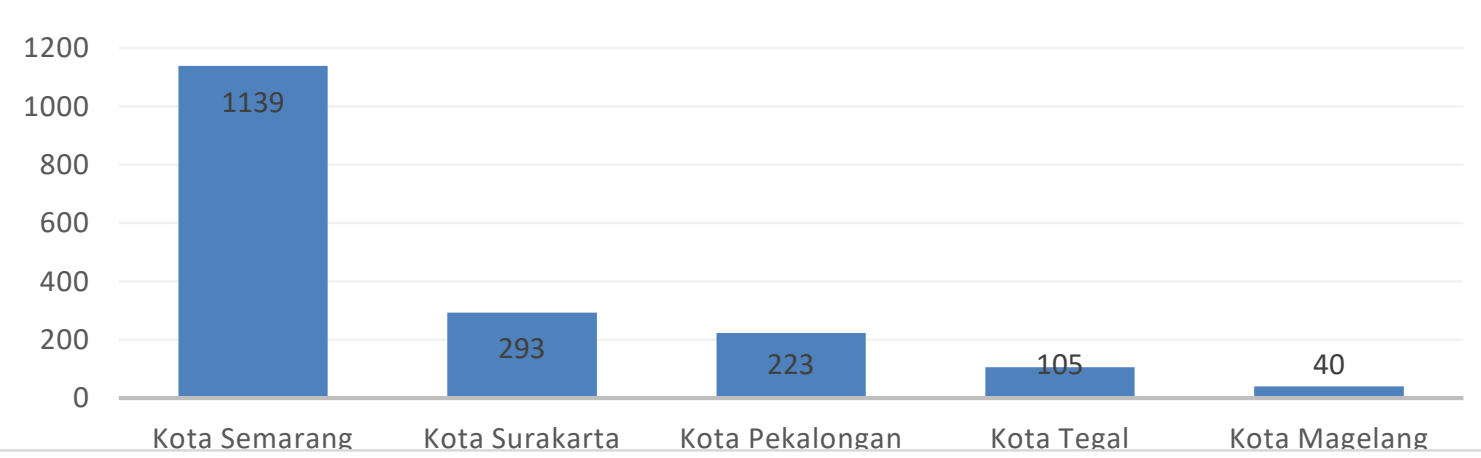

Figure 1. Volume per day of waste generation $\left(\mathrm{m}^{3}\right)$ based on city in Central Java in 2016 Source : Dinas Lingkungan Hidup dan Kehutanan Provinsi Jawa Tengah

Picture 1 shows the municipal waste generation produced by major cities in Central Java. Waste generation volume produced by Semarang has the highest amount of waste generation compared to others. Semarang produces $1139 \mathrm{~m}_{3}$ on daily basis. Waste problem has become a serious problem as it reflects the bad effect of the rapid development activities in Semarang. This can be seen from the increase of waste generation volume years by years. Waste generation is the amount of waste produced by people in either volume or weight unit on daily basis (Ruban 2014). 
Table 1. Total Population, Waste Production and Transported Waste Volume in Semarang City in 2012-2016

\begin{tabular}{lllll}
\hline Year & $\begin{array}{l}\text { Total Population } \\
\text { (Inhabitant) }\end{array}$ & $\begin{array}{l}\text { Waste Production per } \\
\text { Day }\left(\mathrm{m}^{3}\right)\end{array}$ & $\begin{array}{l}\text { Transported } \\
\text { Waste } \\
\text { Volume }\left(\mathrm{m}^{3}\right)\end{array}$ & $\begin{array}{l}\text { Persentage } \\
\text { Transported (\%) }\end{array}$ \\
\hline 2012 & 1.616 .494 & 4757.10 & 3853.25 & 81.00 \\
2013 & 1.644 .374 & 4836.30 & 4014.13 & 83.00 \\
2014 & 1.672 .994 & 4916.82 & 4179.30 & 85.00 \\
2015 & 1.701 .114 & 4998.65 & 4349.00 & 87.00 \\
2016 & 1.729 .083 & 5080.51 & 4445.00 & 87.50 \\
\hline
\end{tabular}

Source : Dinas Lingkungan Hidup Kota Semarang

Based on Table 1 seems that the waste production is equivalent to the growing population. This is a proof that waste production directly proportionate to growing population which means it will need an optimal management to keep environmental sustainability on balance. With an increase in total population, waste production has increased, other than that it also has bad impacts for the goverment if it is not immediately handled then it will need a waste management (Septiawan 2018). Based on the transported waste volume, the percentage in 2016 is $87.50 \%$. This means there are still not transported waste production as much as $12.5 \%$. It will cause further environmental problem to the society if there is no proper solution.

Solid waste generation will increase every day and cannot be stopped but managed, reduced or minimalized properly (Hartono 2006). In other words, it will be needed an efficient and effective management towards waste issue in Semarang. A waste management strategy which considers all the aspects and the management components of solid waste and disposal in turn will help reducing global issue regarding to waste problem (Adenika 2009).

Waste management in Semarang still has a threatening problem to society and environment. Bad management, uncompleted transporting system, lack of tools and limit in final disposal capacity have become the main issue on waste management. The annual growing population in Semarang followed by the increase on waste volume will have to be reckoned for the TPA limit capacity.

Remembering that the availability of the land area is now smaller, the government of Semarang should reduce the household waste resources by holding integrated and comprehensive waste management based on Local Regulation of Semarang City Number 6 Year 2012. In subsection 9 states that everyone in household waste and its kind management must reduce and handle it with environmentally ways. Waste reduction includes limitation activity, reuse and recycle whereas waste handling includes sorting, grouping, transporting, managing and final processing. In its implementation, integrated waste management has not fully operated yet. Based on pre-survey conducted to 30 
respondents in West Semarang District there are 25 or $83 \%$ respondents who do not know about integrated waste management and have not done $3 \mathrm{R}$ concept (Reduce, Reuse, Recycle). Lack of awareness of environment and not yet implementing the ${ }_{3} \mathrm{R}$ concept so that it becomes a waste management issue in West Semarang District.

Pre-survey conducted in West Semarang District as much as $80 \%$ of the respondents said that an improvement on waste management to better the environment quality is needed. It can be done by doing introduction to society, holding waste management training, sorting between organic and inorganic and also adding trash bins.

In order to improve a better waste management surely it costs a lot. According to Rahji (2009), one of the funding sources on waste management can be acquired from the citizens. How much they pay will be determined by the willingness to pay which is called as a desire of the citizens to pay for waste management improvement. Because of that, it needs to do research about how much the willingness to pay of the citizens to improve the environment quality by making waste management better in West Semarang District. From the background above, the researcher wants to know the willingness to pay of West Semarang District's citizens towards integrated waste management improvement and to know the roles of income, level of education, family members and staying duration to willingness to pay of integrated waste management in West Semarang District.

\section{METHOD}

This research is conducted in West Semarang District. This district is chosen as the main location since West Semarang District is one of the most populated and household district followed by the most waste contributing district in Semarang.

The research population is all the households in West Semarang District consist of 16 sub-district with 49344 households. The sample is 100 households obtained by using Slovin formula. It uses purposive sampling. Purposive sampling is selected based on particular characteristics (Sugiyono 2017). Purposive sampling is used in obtaining sample in every sub-district. Only selected by the sub-district government is involved as the sample.

Data analysis method is using contingent valuation method and double linear regression. Contingent valuation method is used to get willingness to pay. In the implementation of Contingent valuation method using direct measurement approach includes building market hypothesis, obtaining willingness to pay value, calculating the willingness to pay average value and summing the data to get total value of willingness to pay (Fauzi 2006).

Multiple linear regression is used to analyze the factors which affect willingness to pay. The formula model used is:

$\mathrm{Y}=\mathrm{a}+\mathrm{b}_{1} \mathrm{X}_{1}+\mathrm{b}_{2} \mathrm{X}_{2}+\mathrm{b}_{3} \mathrm{X}_{3}+\mathrm{b}_{4} \mathrm{X}_{4}+\mathrm{e}$

Where:

$\mathrm{Y}=$ Willingness to pay

$\mathrm{A}=$ Constanta

$\mathrm{X}_{\mathbf{1}}=$ Income (Rupiah)

$\mathrm{B}_{1}=$ Income regression coefficient

$\mathrm{X}_{2}=$ Education level (Year)

b2 = Education regression coefficient

$\mathrm{X}_{3}=$ Family members (person)

b3 = Family member regression coefficient 


$$
\begin{aligned}
& \mathrm{X}_{4}=\text { Staying duration (Year) } \\
& \mathrm{B}_{4}=\text { Staying duration coefficient } \\
& \mathrm{e}=\text { Error }
\end{aligned}
$$

\section{RESULTS AND DISCUSSION}

Geographically, West Semarang District is between $06^{\circ} 57^{\prime} 18^{\prime \prime}-07^{\circ}$ oo' 54 " South Latitude and $110^{\circ} 20^{\prime} 42^{\prime \prime}-110^{\circ} 23^{\prime}$ o6" East Latitude. Contingent Valuation Method approach in this research is used to analyze willingness to pay value towards waste management improvement. Willingness to pay obtained by direct interview with 100 households in West Semarang District through arranged interview guide. Every willingness to pay amount obtained shows the Rupiah amount is paid by some households. From 100 respondents there are 68 people are willing to pay for waste management improvement and 32 respondents say they will not.

Table 2. Value Distribution of Respondent's Willingness To Pay

\begin{tabular}{llll}
\hline No & Willingness To Pay & Total Respondent's & Wtp x Responden's Willing to pay \\
\hline 1 & Rp 4.000 & 1 & Rp 4.000 \\
2 & Rp 5.000 & 3 & Rp 15.000 \\
3 & Rp 7.000 & 2 & Rp 14.000 \\
4 & Rp 7.500 & 1 & Rp 7.500 \\
5 & Rp 8.000 & 2 & Rp 16.000 \\
6 & Rp 10.000 & 19 & Rp 190.000 \\
7 & Rp 12.000 & 3 & Rp 36.000 \\
8 & Rp 12.500 & 1 & Rp 12.500 \\
9 & Rp 15.000 & 12 & Rp 180.000 \\
10 & Rp 20.000 & 7 & Rp 140.000 \\
11 & Rp 25.000 & 9 & Rp 225.000 \\
12 & Rp 30.000 & 4 & Rp 120.000 \\
13 & Rp 35.000 & 1 & Rp 35.000 \\
14 & Rp 50.000 & 3 & Rp 150.000 \\
Total & & 68 & Rp 1.145.000 \\
\hline
\end{tabular}

Source : Processed Primary Data, 2018

The average willingness to pay value of the respondents of West Semarang District is obtained by total ratio value given by the respondents with total amount of respondents who are willing to pay.

$$
\begin{aligned}
& \sum \mathrm{WTP}=(\mathrm{Rp} 1.145 .000) / 68 \\
& \sum \mathrm{WTP}=\operatorname{Rp} 16.838
\end{aligned}
$$

Here is the result of income regression, education level, family members and staying duration towards willingness to pay by using IBM Statistic SPSS 16. Based on Table 3 then obtained a regression formula as follows:

$$
\begin{aligned}
\mathrm{Ln}_{-}= & \text {Ln_WTP=3.005+0,353Ln_Incom } \\
\text { WTP } & \text { e+o.166Ln_Education_Level- - } \\
& \text { o.005Ln_Family_Members+o.2 }
\end{aligned}
$$


99Ln_Staying_Duration

Table 3. Regression Calculation Result

\begin{tabular}{lll}
\hline Variabel & \multicolumn{2}{l}{$\begin{array}{l}\text { Unstandardized } \\
\text { Coeficients }\end{array}$} \\
\cline { 2 - 3 } (Constant) & 3.005 & Std. Error \\
Ln_Income & .533 & .114 \\
Ln_Education_Level & .166 & .195 \\
Ln_Family_Members & -.005 & .155 \\
Ln_Staying_Duration & .229 & .119
\end{tabular}

Source : Processed Primary Data, 2018

Based on the multiple linear regression formula above, can be concluded as follows: Constanta coefficient as much as 3.005 which means if the income, education level, family members and staying duration is o therefore WTP value still in 3.005. Income value as 0.353 means in every increasing income as much as $1 \%$ so the WTP variable will go up around $0.353 \%$. Education level value as 0.166 means in every increasing education level as much as $1 \%$ so the WTP variable will go up around $0.166 \%$. Family members value as -0.005 means in every increasing family members as much as $1 \%$ so the WTP variable will go down around $0.005 \%$. Staying duration value as 0.229 means in every increasing staying duration as much as $1 \%$ so the WTP variable will go up around $0.229 \%$.

Table 4. $\mathrm{t}$ Test Result

\begin{tabular}{lll}
\hline Variabel & $\mathrm{t}$ & $\mathrm{Sig}$ \\
\hline (Constant) & 1.962 & .053 \\
Ln_Income & 3.104 & .003 \\
Ln_Education_Level & .850 & .398 \\
Ln_Family_Members & -.029 & .997 \\
Ln_Staying_Duration & 1.995 & .004 \\
\hline
\end{tabular}

Source : Processed Primary Data, 2018
Based on Table $\mathrm{t}$ obtained table $\mathrm{t}$ (o.025;95) as much as 1.985. Income variable has $t$ value as much as $3.104>1.985$ and $\alpha$ as $0.003<0.05$. This means the hypothesis states that income has positive and significant effect towards willingness to pay is accepted.

Education level variable has $\mathrm{t}$ value as much as $0.850<1.985$ and $\alpha$ as much as $0.398>$ 0.05. This means the hypothesis states that education level has positive and significant effect towards willingness to pay is rejected. The result shows that there are no influence of education level towards willingness to pay. This is because the education in West Semarang District classified to homogeny.

Family members variable has $\mathrm{t}$ value as much as $-0.029<1.985$ and $\alpha$ as much as 0.977 $>$ 0.05. This means the hypothesis states that family members has positive and significant effect towards willingness to pay is rejected. The result shows that there are no influence of family members towards willingness to pay. This is because a perception that the payment is based on Head of the family, not the family members. Staying duration variable has $t$ value as much as $1.995>1.985$ and $\alpha$ as much as $0.004<0.05$. This means the hypothesis states that education level has positive and significant effect towards willingness to pay is accepted.

$F$ test is used to examine the influence amount from all the independent variables simultaneously towards willingness to pay. Then obtained $\mathrm{F}$ value as much as 5.021 with $5 \%$ significance level and degree of freedom (df) 96, obtained F table as much as 2.47. So $5.021>2.47$ which means income, education level, family members and staying duration simultaneously affecting willingness to pay. 
Adjusted R square is used to count the contribution amount of independent variables (income, education level, family members and staying duration) towards dependent variable (willingness to pay). Then obtained total amount of adjusted $\mathrm{R}$ square as much as 0.430 or $43 \%$. It means $43 \%$ willingness to pay caused by income, education level, family members and staying duration variables where the $57 \%$ influenced by another uninspected variables.

Classic assumption test is conducted to know if the estimation model has fulfilled econometric criteria, in other words there is no enough serious violation. Classic assumptions must be fulfilled are normality test, multicolinearity test and heteroscedasticity test.

Normality test is intended to see the significant influence of independent variable towards dependent variable which has standardized residual distribution. In this research, normality test done by using kolmogorov-smirnov statistic test. By using one sample of kolmogorv-smirnov test, on willingness to pay variable obtained Kolmogorv-Smirnov Z as much as 1.096 and Asymp Sig (2-tailed) value as much as $0.593>$ 0.05 which means there is normal distributed unstandardized residual.

Multicolinearity test is intended to examine if there is any linear relations between dependent double regression independent variable or to know partial correlation between independent variables. Table 6 shows the result of multicolinearity test:
Table 5. Multicolinearity Test

\begin{tabular}{|c|c|c|}
\hline \multirow[t]{2}{*}{ Variabel } & \multicolumn{2}{|c|}{ Collinearity Statistics } \\
\hline & Tolerance & VIF \\
\hline \multicolumn{3}{|l|}{ (Constant) } \\
\hline Ln_Income & .742 & 1.348 \\
\hline Ln_Education_Level & .713 & 1.403 \\
\hline Ln_Family_Numbers & .972 & 1.029 \\
\hline Ln_Staying_Duration & .964 & 1.037 \\
\hline \multicolumn{3}{|c|}{ Source : Processed Primary Data, 2018} \\
\hline
\end{tabular}

Table 5 shows that every independent variable has tolerance value $>0.1$ and VIF value $<$ 10. It can be concluded that there is no multicolinearity between independent variable in this regression model. Heteroscedasticity is a condition where variant and bullying error are not constant for all independent variables or to know if there is constant variation or identical. In this research, heteroscedasticity is conducted by observing scatterplot graphic with patterns scattering aboveand below $\mathrm{Y}$ axis.

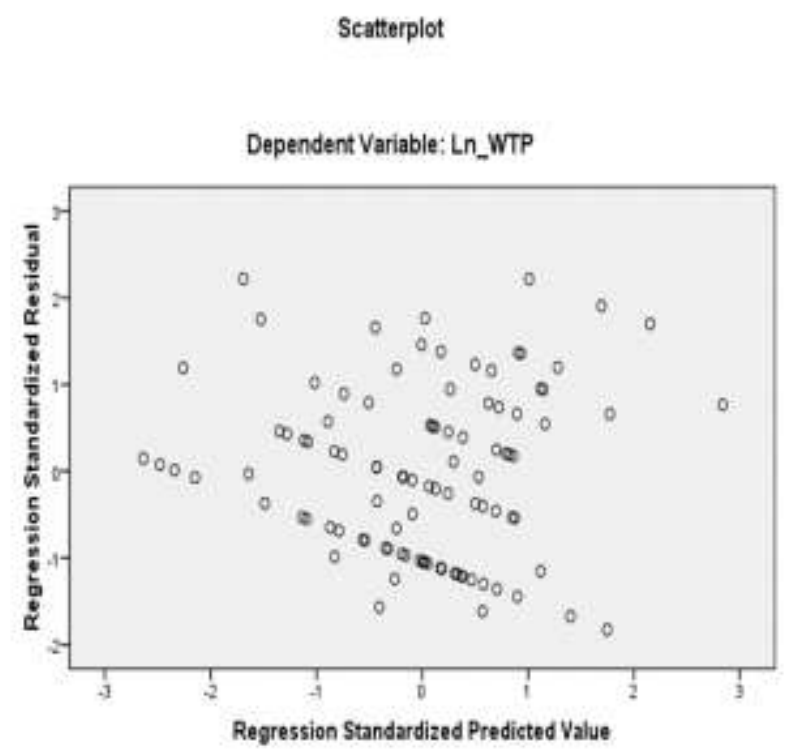

Figure 2. Scatterplot Chart

Source : Processed Primary Data, 2018 
Picture 2 shows that there are dots spreading around randomly both aboveand below zero number in $\mathrm{Y}$ axis on Scatterplot graphic. This means that for dependent and independent variable there is no heteroscedasticity in this regression model.

\section{CONCLUSION}

Based on the data analysis above can be concluded that the respondent's average willingness to pay value on integrated waste management improvement is Rp16.838. Income and staying duration affect willingness to pay in West Semarang District whereas education level and family members do not. Based on Local Regulation of Semarang City Number 12 Year 2012 about retribution shows that citizen's willingness to pay value classified as twice from the monthly retribution. Semarang Government should have adjusted the Local Regulation with the environmental needs. High Willingness to pay should be followed by better management service. Citizens can improve willingness to pay by having higher education level so that they realize the importance of maintaining environment. To increase willingness to pay, the higher family members the more they should have a good knowledge so that their perception about the payment based on head of the family will decrease.

\section{REFERENCES}

Adenika, AA, Titus OB. 2009. Determinats of willingness to pay for improved water supply in Osogbo Metropolis ; Osun State, Nigeria. Research Journal of Social Sciences, 4: 1-6, 2009.
Annisa, Siti. 2015. Analisis Willingness To Pay (WTP) Sampah Rumah Tangga (Studi Kasus Perumnas Kelurahan Simpang Baru Panam Pekanbaru). Jom Fekon Vol. 2 No. 1 Februari 2015.

Badan Lingkungan Hidup dan Kehutanan Provinsi Jawa Tengah, 2017. Kumpulan Data Urusan Lingkungan Hidup. Semarang: Badan lingkungan Hidup dan Kehutanan.

Badan Pusat Statistik Jakarta Pusat, 2017. Statistik Lingkungan Hidup 2017. Jakarta Pusat: Badan Pusat Statistik.

Badan Pusat Statistik Kota Semarang, 2017. Kecamatan Semarang Barat Dalam Angka 2017. Semarang: badan Pusat Statistik.

Fauzi, Akhmad. 2006. Ekonomi Sumber Daya Alam dan Lingkungan. Jakarta: PT. Gramedia Pustaka Utama.

Ghozali, Imam. 2009. Ekonometrika Teori, Konsep dan Aplikasi dengan SPSS 17. Semarang: Badan Penerbit Universitas Diponegoro.

Hartono, Edi. 2006. "Peningkatan Pelayanan pengelolaan Sampah di Kota Brebes Melalui Peningkatan Kemampuan Pembiayaan”. Tesis. Pasca Sarjana Universitas Diponegoro.

Rahji, Elizabeth \& O. Oloruntoba. 2009. Determinants of households' willingness-to-pay for private solid waste management services in Ibadan, Nigeria. Journals Permissions ISSN 0734-242X Waste Management \& Research 2009: 27: 961-965.

Reksohadiprodjo, Sukanto dan Andreas budi. 2000. Ekonomi Lingkungan (Suatu Pengantar) Edisi 2. Yogyakarta. BPFE Yogyakarta.

Ruban, Angela dan Eka Intan Kumala. 2014. Willingness To Pay Masyarakat Terhadap Pengelolaan Sampah Ramah Lingkungan di TPA Dusun Toisapu Kota Ambon. Jurnal Ekonomi pertanian, sumberdaya dan lingkungan 1 (2014) 102-113.

Sugiyono. 2017. Metode Penelitian Kuantitatif, Kualitatif, dan R\&D. Bandung. Penerbit Alfabeta Bandung.

Septiawan, Ivan. 2018. Strategi Peningkatan Pengelolaan Persampahan di Kecamatan Ngaliyan Kota Semarang. Economics Development Analysis $\begin{array}{llllll}\text { Journal } & 7 & \text { (2) } & \text { (2018). Hal } & \text { 111-119 }\end{array}$ 